\title{
Non Medical Factors That Affect Usage Of Long Acting Reversible Contraceptive (LARC) in Women After Childbirth in Indonesia
}

\author{
Cindra Paskaria
}

\author{
Department of Public Health, Faculty of Medicine, Maranatha Christian University \\ Jl. Prof. Drg. Suria Sumantri MPH No. 65 Bandung 40164, Indonesia \\ Email:cpaskaria@yahoo.com
}

\begin{abstract}
The Long Acting Reversible Contraceptive (LARC) is a method of contraception that is effective and efficient to prevent pregnancy or limit births, but its use in Indonesia is still low especially in women after childbirth. This may increase the risk of unwanted pregnancy and short birth interval. The purpose of this research is to find out what factors affect the use of LARC in women after childbirth in Indonesia. This research is an analysis of secondary data Indonesia Demographic and Health Survey 2012, with stamp 3,918 Women's Reproductive Age, which is between 15-49 years old and they had given birth one year before the survey. The data were analyzed by using simple logistic regression analysis. This research shows that the proportion of women who used LARC after childbirth in Indonesia in 2012 was $7.31 \%$ and it was influenced by the level of socio-economic, domiciles, the husband's level of education, the number of children born alive, the number of children still living, the desired number of children, the role of husband, and the role of religious figures.
\end{abstract}

Keywords: LARC, women after childbirth, non medical factors 


\title{
Faktor - Faktor Non Medis yang Mempengaruhi Penggunaan Metode Kontrasepsi Jangka Panjang (MKJP) pada Wanita Pascasalin di Indonesia
}

\author{
Cindra Paskaria \\ Bagian Ilmu Kedokteran Masyarakat, \\ Fakultas Kedokteran, Universitas Kristen Maranatha \\ J1. Prof. Drg. Suria Sumantri MPH No. 65 Bandung 40164, Indonesia \\ Email : cpaskaria@yahoo.com
}

\begin{abstract}
ABSTRAK
Metode Kontrasepsi Jangka Panjang (MKJP) merupakan metode kontrasepsi yang efektif dan efisien untuk mencegah kehamilan atau menjarangkan kelahiran, namun penggunaannya di Indonesia masih rendah terutama pada wanita pascasalin. Hal ini dapat meningkatkan risiko kehamilan yang tidak diinginkan dan interval kelahiran yang pendek. Tujuan penelitian ini adalah untuk mengetahui faktor-faktor yang mempengaruhi penggunaan MKJP pada wanita pascasalin di Indonesia. Penelitian ini merupakan analisis data sekunder Survei Demografi Kesehatan Indonesia 2012, dengan sampel 3918 wanita usia subur umur 15-49 tahun yang melahirkan 1 tahun sebelum survei. Data dianalisis menggunakan uji regresi logistik sederhana. Penelitian menunjukkan bahwa proporsi penggunaan MKJP pascasalin di Indonesia tahun 2012 adalah sebesar 7,31 persen dan faktor yang mempengaruhi penggunaan MKJP pada wanita pascasalin adalah tingkat sosial ekonomi, tempat tinggal, pendidikan suami, jumlah anak lahir hidup, jumlah anak masih hidup, jumlah anak yang diinginkan, peran suami dan peran tokoh agama.
\end{abstract}

Kata Kunci : MKJP, wanita pascasalin, faktor-faktor non medis 


\section{Research Article}

\section{Pendahuluan}

Pemerintah menetapkan program Keluarga Berencana di Indonesia pertama kali pada tanggal 29 Juni 1970, namun sampai saat ini program KB masih menjadi urusan kesehatan dan belum menjadi urusan kependudukan. Menurut World Population Data Sheet 2013, Indonesia merupakan Negara ke-5 di dunia dengan estimasi jumlah penduduk terbanyak, yaitu 249 juta. Angka fertilitas total (Total Fertility Rate atau TFR) Indonesia sebesar 2,6 ; yang berarti seorang wanita di Indonesia rata-rata melahirkan 2,6 anak selama masa reproduksinya. ${ }^{1}$ Hasil proyeksi Badan Pusat Statistik (BPS), jumlah penduduk Indonesia pada tahun 2035 sekitar 305,6 juta jiwa, sehingga pengendalian fertilitas perlu terus dilakukan melalui penggunaan kontrasepsi yang lebih diarahkan kepada pemakaian Metode Kontrasepsi Jangka Panjang (MKJP). ${ }^{2}$

MKJP adalah kontrasepsi yang dapat dipakai dalam jangka waktu lama, lebih dari dua tahun, efektif dan efisien untuk tujuan menjarangkan kelahiran lebih dari 3 tahun atau mengakhiri kehamilan pada pasangan yang sudah tidak ingin menambah anak lagi. Jenis metode yang termasuk dalam kelompok ini adalah metode kontrasepsi mantap (pria dan wanita), implan dan Intra Uterine Device (IUD). ${ }^{2}$ Efektivitas MKJP cukup tinggi dan angka kegagalan rendah. Angka kegagalan IUD adalah 0,6 - 0,8 kehamilan per 100 perempuan dalam 1 tahun pertama, implan 0,2 - 1 kehamilan per 100 perempuan dan kontrasepsi mantap 0,2-4 kehamilan per 100 perempuan. ${ }^{3}$

Pada tahun 2007 pemakaian kontrasepsi pada wanita menikah di Indonesia sebesar 61\% kemudian meningkat menjadi 62\% pada tahun 2012, angka penggunaan kontrasepsi modern juga meningkat dari 57\% menjadi 58\%, namun sayangnya angka pemakaian MKJP masih rendah. Wanita menikah di Indonesia lebih banyak memilih metode suntikan atau pil dibandingkan MKJP. Angka peserta KB IUD (Intra Uterine Device) mengalami penurunan dari 13\% pada tahun 1991 menjadi 4\% pada tahun 2012, peserta KB implan 3,3\%, kontrasepsi mantap pria 0,2\% dan kontrasepsi mantap wanita $3,2 \%{ }^{4}$

Kontrasepsi diperlukan untuk mencegah kehamilan dengan cara mengurangi peluang terjadinya konsepsi pada setiap siklus ovulasi. Pada periode pascasalin kontrasepsi memiliki peranan penting untuk mencegah kehamilan yang tidak diinginkan dan memperpanjang interval kelahiran, sehingga mengurangi risiko kematian bayi dan ibu. Berdasarkan kesepakatan global (Millenium Development Goals/MDG's2000) diharapkan angka kematian ibu menurun dari 228 pada tahun 2007 menjadi 102 dan angka kematian bayi menurun dari 34 pada tahun 2007 menjadi 23 pada tahun $2015 .^{5}$

Penelitian Ross dan Winfrey (2001) di 27 negara, menunjukkan rendahnya penggunaan kontrasepsi pascasalin, padahal sebagian besar dari wanita pascasalin sudah tidak ingin mempunyai 


\section{Research Article}

anak lagi atau ingin menjarangkan kehamilannya sehingga risiko kehamilan yang tidak diinginkan semakin tinggi, hal ini juga berisiko terhadap kesehatan ibu dan anak. ${ }^{6}$

Salah satu penyebab tingginya angka kematian ibu di Indonesia adalah kehamilan yang tidak diinginkan. Berdasarkan laporan hasil Riset Kesehatan Dasar (Riskesdas) 2010, persentase pengguguran adalah 3,5\%. Sebesar 6,5\% dari mereka yang mengalami keguguran, berusaha untuk mengakhiri kehamilannya. 24,4\% responden mengemukakan bahwa alasan untuk pengguguran adalah karena jarak kehamilan terlalu dekat, padahal hal ini sebenarnya dapat dicegah dengan penggunaan alat kontrasepsi. ${ }^{7}$ Risiko kematian akibat pengguguran yang dilakukan pada 2 bulan pertama adalah sekitar 0,6 per 100.000 tindakan. Risiko relatif meninggal akibat pengguguran meningkat sekitar dua kali lipat untuk setiap penundaan 2 minggu setelah kehamilan 8 minggu. ${ }^{8}$

Kehamilan dengan interval kelahiran yang pendek juga berisiko terhadap kesehatan bayi dan ibu. Penelitian Rutstein tahun 2005 menunjukkan bahwa interval kelahiran kurang dari 36 bulan berkaitan dengan meningkatnya kejadian kurang gizi, risiko kesakitan dan kematian pada anak, risiko ini akan lebih tinggi pada interval kurang dari 24 bulan. Angka mortalitas akan meningkat pada interval lebih dari sama dengan 60 bulan, sehingga peneliti merekomendasikan interval kelahiran optimal pada 36-59 bulan. $^{2}$ Sebuah penelitian di India memberikan kesimpulan bahwa peluang bayi dan ibu untuk bertahan hidup 2,5 kali lebih besar pada interval kelahiran 3-5 tahun dibandingkan interval $\leq 2$ tahun. ${ }^{9}$

Berdasarkan latar belakang ini, peneliti ingin mengetahui faktor non medis apa saja yang mempengaruhi penggunaan MKJP pada wanita pascasalin di Indonesia tahun 2012, sehingga hasil penelitian ini dapat menjadi salah satu masukan bagi pemerintah dalam meningkatkan cakupan penggunaan MKJP pascasalin di Indonesia

\section{Metode}

Penelitian ini merupakan data cross sectional yang menggunakan data sekunder dari SDKI tahun 2012. Populasi penelitian adalah semua wanita usia subur (15-49 tahun) di Indonesia. Kriteria inklusi dalam pengambilan sampel pada penelitian ini adalah wanita usia subur (15-49 tahun) yang pernah melahirkan dalam waktu satu tahun terakhir sebelum survei, sedangkan kriteria eksklusinya adalah responden yang tidak memiliki data yang lengkap, sehingga diperoleh sampel sebesar 3.918.

Analisis data dilakukan dengan metode complex sample, hal ini dilakukan karena data yang digunakan adalah data SDKI yang diperoleh dengan cara non-SRS (simple random sampling), sehingga dalam analisis data dibutuhkan strata, klaster dan pembobotan. Analisis data dilakukan melalui dua tahapan, yaitu analisis univariabel untuk melihat distribusi frekuensi pada tiap variabel 


\section{Research Article}

penelitian. Selanjutnya analisis bivariabel dengan menggunakan uji regresi logistik sederhana untuk melihat proporsi dan kemaknaan hubungan variabel independen dengan variabel dependen.

\section{Hasil}

Tabel 1 Gambaran Karakteristik Responden

\begin{tabular}{|c|c|c|}
\hline Variabel & Proporsi (persen) & $\mathbf{N}$ \\
\hline \multicolumn{3}{|l|}{ Pendidikan Ibu } \\
\hline - Rendah & 31,23 & 1209 \\
\hline - $\quad$ Tinggi & 68,77 & 2709 \\
\hline \multicolumn{3}{|c|}{ Tingkat Sosial Ekonomi } \\
\hline - $\quad$ Miskin & 41,36 & 1963 \\
\hline - Mampu & 58,64 & 1955 \\
\hline \multicolumn{3}{|l|}{ Tempat Tinggal } \\
\hline - $\quad$ Pedesaan & 50,68 & 2149 \\
\hline - $\quad$ Perkotaan & 49,32 & 1769 \\
\hline \multicolumn{3}{|l|}{ Pendidikan Suami } \\
\hline - $\quad$ Rendah & 32,38 & 1245 \\
\hline - $\quad$ Tinggi & 67,62 & 2673 \\
\hline \multicolumn{3}{|c|}{ Jumlah Anak Lahir Hidup } \\
\hline$\bullet 0-2$ anak & 70,96 & 2588 \\
\hline - Lebih dari 2 anak & 29,04 & 1330 \\
\hline \multicolumn{3}{|c|}{ Jumlah Anak Masih Hidup } \\
\hline • $0-2$ anak & 73,63 & 2704 \\
\hline - Lebih dari 2 anak & 26,37 & 1214 \\
\hline \multicolumn{3}{|c|}{ Jumlah Anak yang Diinginkan } \\
\hline - Lebih dari 2 anak & 42,99 & 1840 \\
\hline - $0-2$ anak & 57,01 & 2078 \\
\hline \multicolumn{3}{|l|}{ Dukungan Suami } \\
\hline - Tidak & 35,76 & 1503 \\
\hline - $\mathrm{Ya}$ & 64,24 & 2415 \\
\hline \multicolumn{3}{|c|}{ Dukungan Tokoh Agama } \\
\hline - Tidak & 98,9 & 3884 \\
\hline - $\mathrm{Ya}$ & 1,1 & 34 \\
\hline
\end{tabular}

Sebagian besar responden (66,85 persen) menggunakan metode kontrasepsi setelah melahirkan anak terakhirnya, meskipun demikian proporsi penggunaan MKJP pascasalin hanya sekitar 7,31 persen. Dari keempat jenis MKJP, IUD merupakan metode yang paling banyak dipakai oleh responden sedangkan metode sterilisasi pria paling sedikit digunakan. Secara keseluruhan responden paling banyak menggunakan metode kontrasepsi suntikan dan pil, bahkan masih ada yang menggunakan metode tradisional. 


\section{Research Article}

Sebagian besar responden berpendidikan tinggi dengan tingkat sosial ekonomi mampu dan tinggal di wilayah pedesaan. Sebanyak 57,01 persen responden menginginkan jumlah anak 0 sampai dengan 2, sesuai dengan kondisi yang ada bahwa lebih banyak responden yang memiliki anak yang dilahirkan hidup dan anak masih hidup berjumlah 0 sampai 2 anak.

Sebanyak 64,24 persen responden mendapat dukungan dari suami untuk menggunakan alat kontrasepsi. Responden masih kurang mendapatkan informasi mengenai kontrasepsi dari tokoh agama selama 6 bulan terakhir, tetapi responden mendapatkan informasi mengenai KB dari media massa seperti radio, televisi, koran atau majalah dengan proporsi 51,74 persen.

Berdasarkan tabel 1, diketahui bahwa faktor yang mempengaruhi penggunaan MKJP pada wanita pascasalin adalah tingkat sosial ekonomi, tempat tinggal, pendidikan suami, jumlah anak lahir hidup, jumlah anak masih hidup, jumlah anak yang diinginkan, peran suami dan peran tokoh agama. Hal ini tidak hanya dilihat dari $P$ value saja, tetapi juga mempertimbangkan nilai odds ratio dan 95 persen confidence interval. Berdasarkan uji regresi logistik sederhana diketahui bahwa responden dengan tingkat sosial ekonomi mampu, tinggal di perkotaan, pendidikan suami tinggi, jumlah anak lahir hidup lebih dari 2, jumlah anak masih hidup lebih dari 2, jumlah anak yang diinginkan 0-2 anak, mendapat dukungan dari suami dan mendapat informasi mengenai KB dari tokoh agama, lebih besar kemungkinannya untuk menggunakan MKJP pada periode pascasalin.

Tabel 2 Faktor Yang Mempengaruhi Penggunaan Metode Kontrasepsi Jangka Panjang (MKJP) pada Wanita Pascasalin

\begin{tabular}{|c|c|c|c|c|}
\hline \multirow{2}{*}{ Variabel } & \multicolumn{2}{|c|}{ Penggunaan MKJP pascasalin } & \multirow{2}{*}{$\begin{array}{l}\text { Odds Ratio } \\
\text { (95\% CI) }\end{array}$} & \multirow{2}{*}{ P value } \\
\hline & $\begin{array}{c}\text { Tidak } \\
\text { menggunakan } \\
\text { (persen) }\end{array}$ & $\begin{array}{c}\text { Menggunakan } \\
\text { (persen) }\end{array}$ & & \\
\hline \multicolumn{5}{|l|}{ Pendidikan Ibu } \\
\hline - Tinggi & 92,24 & 7,76 & $1,25(0,84-1,87)$ & 0,277 \\
\hline \multicolumn{5}{|c|}{ Tingkat Sosial Ekonomi } \\
\hline - Miskin & 94,8 & 5,2 & & \\
\hline - Mampu & 91,2 & 8,8 & $1,76(1,22-2,53)$ & 0,002 \\
\hline \multicolumn{5}{|l|}{ Tempat Tinggal } \\
\hline - Pedesaan & 93,77 & 6,23 & & \\
\hline - Perkotaan & 91,59 & 8,41 & $1,38(0,93-2,05)$ & 0,106 \\
\hline \multicolumn{5}{|l|}{ Pendidikan Suami } \\
\hline - Rendah & 94,71 & 5,29 & & \\
\hline - Tinggi & 91,73 & 8,27 & $1,61(1,06-2,47)$ & 0,027 \\
\hline \multicolumn{5}{|c|}{ Jumlah Anak Lahir Hidup } \\
\hline - $0-2$ anak & 94,16 & 5,84 & & \\
\hline - Lebih dari 2 anak & 89,11 & 10,89 & $1,97(1,35-2,86)$ & 0,000 \\
\hline
\end{tabular}




\section{Research Article}

\begin{tabular}{|c|c|c|c|c|}
\hline \multicolumn{5}{|c|}{ Jumlah Anak Masih Hidup } \\
\hline - $0-2$ anak & 94,08 & 5,92 & & \\
\hline - Lebih dari 2 anak & 88,82 & 11,18 & $2,00(1,40-2,85)$ & 0,000 \\
\hline \multicolumn{5}{|c|}{ Jumlah Anak yang Diinginkan } \\
\hline - Lebih dari 2 anak & 93,95 & 6,05 & & \\
\hline - $0-2$ anak & 91,74 & 8,26 & $1,40(0,96-2,03)$ & 0,078 \\
\hline \multicolumn{5}{|l|}{ Peran Suami } \\
\hline - Tidak & 98,99 & 1,01 & & \\
\hline - $\mathrm{Ya}$ & 89,19 & 10,81 & $11,90(4,61-30,77)$ & 0,000 \\
\hline \multicolumn{5}{|l|}{ Peran Tokoh Agama } \\
\hline - Tidak & 92,8 & 7,2 & & \\
\hline - $\mathrm{Ya}$ & 83,24 & 16,76 & $2,59(0,70-9,64)$ & 0,155 \\
\hline
\end{tabular}

\section{Diskusi}

Pedoman Pelayanan KB dan KIA mengarahkan pelayanan KB pascasaln pada penggunaan MKJP karena memiliki efektivitas dan efisiensi yang tinggi. Berdasarkan analisis, sebagian besar ibu pascasalin telah menggunakan metode kontrasepsi, namun secara keseluruhan proporsi penggunaan MKJP pascasalin masih rendah, hanya sekitar 7,31 persen. Metode kontrasepsi yang paling banyak digunakan adalah non MKJP yaitu suntikan dan pil. Kaum ibu cenderung merasa enggan untuk menggunakan MKJP dengan beberapa alasan diantaranya ; takut terhadap tindakan pembedahan minor untuk pemasangan dan pencabutan implan, takut dan malu dilakukan pemeriksaan dalam pada pemasangan IUD, biaya yang cukup tinggi untuk dilakukannya sterilisasi dan sifat permanen dari metode kontrasepsi mantap (kecuali dengan operasi rekanalisasi). Anna Glassier tahun 2008 melakukan penelitian di Skotlandia dengan metode focused group discussion (FGD), berdasarkan penelitiannya diperoleh keseimpulan bahwa para wanita kurang memiliki informasi mengenai MKJP dan banyak pandangan yang salah mengenai efektifitas dan efek samping MKJP. Mereka kurang menyukai MKJP karena memerlukan tindakan yang invasif dan pemeriksaan dalam pada pemasangan IUD. Komunikasi, Informasi dan Edukasi (KIE) yang jelas dan lengkap dari petugas kesehatan diharapkan dapat memperbaiki sikap dan perilaku wanita terhadap MKJP. ${ }^{10}$

Responden yang memiliki jumlah anak masih hidup lebih dari dua, 2 kali lebih besar kemungkinannya untuk menggunakan MKJP dibandingkan yang memiliki anak masih hidup 0-2 anak, sedangkan responden yang memiliki jumlah anak lahir hidup lebih dari dua anak, 1,97 kali lebih besar kemungkinannya untuk menggunakan MKJP dibandingkan yang memiliki anak lahir hidup 0-2 anak. Terlihat bahwa ibu yang memiliki anak lebih dari dua lebih memiliki kesadaran untuk menggunakan MKJP sebagai metode kontrasepsi yang efektif untuk membatasi jumlah anak.

Responden yang menginginkan jumlah anak 0-2, 1,40 kali lebih besar kemungkinannya untuk menggunakan MKJP dibandingkan yang menginginkan anak lebih dari 2. Tingginya efektivitas MKJP 


\section{Research Article}

dapat menolong ibu untuk mewujudkan keinginannya dalam membatasi jumlah anak. 56,6 persen responden menginginkan jumlah anak 0-2, hal ini menunjukkan bahwa masyarakat Indonesia tidak lagi cenderung memiliki prinsip "banyak anak banyak rejeki" dan sudah ada kesadaran akan pentingnya membatasi jumlah anak, namun sayangnya hal ini tidak dibarengi penggunaan MKJP pascasalin. Penggunaan MKJP hanya sekitar 7,54 persen, sehingga angka unmet need MKJP pada ibu pascasalin cukup tinggi. Unmeet need adalah jumlah pasangan usia subur yang ingin menunda kehamilan atau tidak menginginkan tambahan anak lagi tetapi tidak berKB.

Responden yang memiliki tingkat sosial ekonomi mampu, 1,76 kali lebih besar kemungkinannya untuk menggunakan MKJP pascasalin dibandingkan dengan tingkat sosial ekonomi miskin. Seharusnya ekonomi tidak lagi menjadi kendala bagi ibu untuk mendapatkan pelayanan KB pascasalin, karena sejak Januari 2011 program Jampersal mulai dilaksanakan di Indonesia. Jampersal merupakan kependekan dari Jaminan Persalinan, artinya jaminan pembiayaan yang digunakan untuk pemeriksaan kehamilan, pertolongan persalinan, pelayanan nifas termasuk pelayanan KB pascasalin dan pelayanan bayi baru lahir, yang pembiayaannya dijamin oleh pemerintah, saat ini program Jampersal sudah terintegrasi dengan program Jaminan Kesehatan Nasional (JKN). Faktor akses terhadap sarana kesehatan atau pelayanan KB dapat menjadi salah satu kendala bagi ibu dengan tingkat sosial ekonomi yang rendah untuk mendapatkan pelayanan KB pascasalin, karena program Jampersal hanya berlaku jika pelayanan kesehatan dilakukan di sarana kesehatan.

Faktor sosial ekonomi berpengaruh pada penggunaan MKJP pascasalin karena sebagian besar pemakai kontrasepsi harus membayar untuk mendapatkan pelayanan KB. 23 persen pemakai kontrasepsi memperoleh cara atau alat kontrasepsi dari tempat pelayanan pemerintah, dan sebagian besar dari mereka (16 persen) membayar untuk alat kontrasepsi dan jasa pelayanannya. 73 persen pemakai kontrasepsi menggunakan fasilitas pelayanan swasta, dan kebanyakan dari mereka (70 persen) membayar.

BKKBN sudah mengeluarkan kebijakan bahwa pelayanan MKJP khususnya IUD dan sterilisasi pria diberikan secara gratis kepada masyarakat, baik di fasilitas kesehatan milik pemerintah maupun swasta. Kebijakan ini perlu didukung oleh pengawasan yang baik terhadap penyedia pelayanan KB, karena seringkali mereka masih menarik biaya terhadap peserta KB.

Pada studi Pemantauan Pelaksanaan Kebijakan Jampersal dan BOK yang dilakukan di Papua Barat, Yogyakarta dan NTT diperoleh hasil bahwa masih ada biaya yang harus dikeluarkan oleh masyarakat pada program Jampersal, yang salah satu penyebabnya adalah ketidakpuasan sektor swasta terhadap jumlah pembayaran yang dibayarkan oleh Jampersal, sehingga provider cenderung menutupi informasi mengenai program Jampersal dari masyarakat. ${ }^{11}$ 


\section{Research Article}

Responden yang tinggal di perkotaan, 1,38 kali lebih besar kemungkinannya untuk menggunakan MKJP pascasalin dibandingkan dengan yang tinggal di pedesaan. Pada umumnya ibu di pedesaan kurang memiliki akses terhadap informasi kesehatan, dengan pengetahuan yang rendah ibu akan merasa aman dan menjadi pasif, maka KIE mengenai KB perlu di tingkatkan terutama bagi ibu di pedesaan.

Responden yang mendapatkan informasi mengenai KB dari tokoh agama selama 6 bulan terakhir, 2,59 kali lebih besar kemungkinannya untuk menggunakan MKJP pascasalin dibandingkan dengan yang tidak mendapatkan informasi dari tokoh agama. Hal ini menunjukkan masih tingginya kepercayaan masyarakat terhadap tokoh agama, sehingga ini dapat menjadi salah satu strategi promosi program KB.

Responden yang mendapatkan dukungan dari suami untuk menggunakan kontrasepsi, 11,90 kali lebih besar kemungkinannya untuk menggunakan MKJP dibandingkan yang tidak mendapatkan dukungan dari suami. Petugas kesehatan perlu memberikan penjelasan kepada pasangan usia subur, bahwa tanggung jawab ber-KB bukan hanya pada istri, tetapi juga menjadi tanggung jawab suami. Suami dapat terlibat langsung menggunakan metode kontrasepsi, seperti vasektomi, kondom, sanggama terputus dan sistem kalender. Bentuk keterlibatan suami secara tidak langsung antara lain dengan mendukung istri untuk memilih kontrasepsi yang sesuai dengan kondisinya, mengingatkan istri untuk memeriksakan IUD secara teratur, membantu mencari pengobatan medis ketika istri mengalami komplikasi penggunaan kontrasepsi dan memutuskan secara bersama dengan istri mengenai jumlah anak yang diinginkan. Dari hasil penelitian juga terlihat bahwa istri yang suaminya berpendidikan tinggi, 1,61 kali lebih besar kemungkinannya untuk menggunakan MKJP dibandingkan yang berpendidikan rendah. Suami yang berpendidikan tinggi diharapkan memiliki pengetahuan yang lebih baik khususnya mengenai KB sehingga dapat mendukung istrinya untuk menggunakan metode kontrasepsi yang tepat.

Berdasarkan gambaran karakteristik responden dapat terlihat bahwa sebenarnya responden memiliki karakteristik yang mendukung penggunaan MKJP pascasalin, namun dalam kenyataannya proporsi penggunaan MKJP pascasalin masih rendah. Perlu dipikirkan faktor petugas kesehatan sebagai penyedia layanan KB-MKJP yang menyebabkan hal ini. Sebagian besar pengguna kontrasepsi menggunakan jasa bidan swasta untuk mendapatkan pelayanan KB. Bidan swasta harus terdaftar sebagai Bidan Delima untuk dapat memberikan pelayanan IUD, dengan berbagai persyaratan dan pelatihan yang harus dijalani, kondisi ini semakin membatasi bidan untuk memberikan pelayanan IUD. 


\section{Research Article}

\section{Simpulan}

1. Proporsi penggunaan MKJP pascasalin di Indonesia masih rendah dibandingkan dengan non MKJP.

2. Faktor non medis yang mempengaruhi penggunaan MKJP pada wanita pascasalin adalah tingkat sosial ekonomi, tempat tinggal, pendidikan suami, jumlah anak lahir hidup, jumlah anak masih hidup, jumlah anak yang diinginkan, peran suami dan peran tokoh agama.

\section{Daftar Pustaka}

1. Kemenkes RI. Situasi dan Analisis Keluarga Berencana. Jakarta; 2014

2. Leli A, Hadriah O. Faktor yang Mempengaruhi Pemakaian Kontrasepsi Jangka Panjang (MKJP). Puslitbang KB dan Kespro BKKBN; 2009

3. BKKBN. Pedoman Pelayanan Keluarga Berencana Pasca Persalinan di Fasilitas Kesehatan; 2012

4. BPS RI. Survei Demografi dan Kesehatan Indonesia 2012. Jakarta; 2013

5. Kemenkes RI. Peraturan Menteri Kesehatan Republik Indonesia Nomor 2562 / MENKES / PER / XII / 2011 (Tentang petunjuk teknis jaminan persalinan). Jakarta; 2011

6. John A, William L. Contraceptive Use, Intention To Use and Unmet Need During The Extended Postpartum Period. International Family Planning Perspectives. 2001; 27(1):20-7

7. Kemenkes RI. Riset Kesehatan Dasar, Badan Penelitian dan Pengembangan Kesehatan. Jakarta. 2010

8. Gary C. Obstetri Williams. Jakarta. EGC; 2005

9. Mary P, Mohammed E, Kaushal K, Rukma I. Increasing Postpartum Contraception in Rural India: Evaluation of a Community-Based Behavior Change Communication Intervention. International Perspectives on Sexual and Reproductive Health. 2012. 38(2):68-77

10. Glasier A, Scorer J, Bigrigg A. Attitudes of Women in Scotland to Contraception: A Qualitative Study to Explore The Acceptability of Long-Acting Methods. J Fam Plann Reprod Health Care. 2008. 34(4):213-7

11. Laksono T, Sigit R, Tudiono. Monitoring Pelaksanaan Kebijakan BOK dan Jampersal. Diunduh Juni 2014. http://www.kesehatanibu.depkes.go.id 